Volume 10 Number 4, October-December 2016: pp. 605-820. Copyright (c) 2015-2016 FIAT JUSTISIA. Faculty of Law, Lampung University, Bandarlampung, Lampung, Indonesia. ISSN: 1978-5186 | e-ISSN: 2477-6238.

Open Access: http://jurnal.fh.unila.ac.id/index.php/fiat

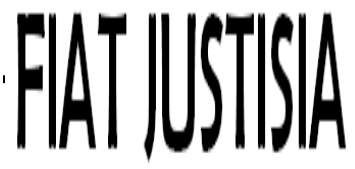

Fiat Justisia is licensed under a Creative Commons Attribution 4.0 International License, which permits unrestricted use, distribution, and reproduction in any medium, provided the original work is properly cited.

\title{
PENCEGAHAN KECURANGAN (FRAUD) DALAM PELAKSANAAN PROGRAM JAMINAN KESEHATAN PADA SISTEM JAMINAN SOSIAL KESEHATAN (SJSN) DI RUMAH SAKIT UMUM DAERAH MENGGALA TULANG BAWANG
}

\section{Prevention of Fraudulent in the Implementation of Health Insurance Program on National Social Security System (SJSN) in Menggala Hospital}

\author{
Tatik Sri Hartati \\ Rumah Sakit Umum Daerah Menggala Tulang Bawang \\ Email: tatikarham77@gmail.com
}

\begin{abstract}
JKN fraud prevention systems in hospitals Menggala as Referral Health Facility Advanced (FKRTL). With creating Fraud Prevention Team, based on Decree of Hospital Director Menggala with SK No. 800/876/III.12/TB/IX/2015 About Fraud Prevention Team. One of the team task activity is to undertake prevention, detection and prosecution of fraud $J K N$. The system has been built in an effort to prevent hospitals Menggala $J K N$ in accordance with the Decree by health minister regulation No. 36 Year 2015. System complaints or reports of fraud in hospitals Menggala JKN performed by writing format addressed to the Fraud Prevention Team. Complaints or reports of alleged fraud JKN, must consist of at least include: identity of the complainant, name and address of the agency that was suspected doing fraud action JKN, and the reason for the complaint. In the event of the case if there any disagreement on the determination of whether there is a fraud JKN or none, the Provincial Health Office or the District Health Office/City may forward complaints to fraud prevention team JKN was established by the Minister.
\end{abstract}

Keywords: Cheating (fraud), prevention, complaint 


\begin{abstract}
Abstrak
Sistem pencegahan kecurangan JKN di rumah sakit Menggala sebagai Rujukan Sarana Kesehatan Lanjutan (FKRTL). Dengan membuat Tim Pencegahan Penipuan, berdasarkan Keputusan Direktur Teknik Menggala dengan SK No. 800/876/III.12/TB/IX/2015 tentang Tim Pencegahan Penipuan. Salah satu tugas tim adalah melakukan pencegahan, deteksi dan penuntutan kecurangan JKN. Sistem ini telah dibangun dalam upaya mencegah rumah sakit Menggala JKN sesuai dengan Keputusan Menteri Kesehatan No. 36 Tahun 2015. Keluhan Sistem atau laporan kecurangan di rumah sakit Menggala JKN dilakukan dengan cara menulis format yang ditujukan kepada Tim Pencegahan Penipuan. . Keluhan atau laporan dugaan kecurangan JKN, setidaknya harus terdiri dari: identitas pengadu, nama dan alamat instansi yang diduga melakukan tindakan kecurangan JKN, dan alasan pengaduannya. Apabila terjadi perselisihan mengenai penentuan apakah ada kecurangan JKN atau tidak, Dinas Kesehatan Provinsi atau Dinas Kesehatan/Kota dapat meneruskan pengaduan ke tim pencegahan kecurangan JKN yang ditetapkan oleh Menteri
\end{abstract}

Kata Kunci: Kecurangan, pencegahan, keluhan

\title{
A. Pendahuluan
}

Kesehatan merupakan hak asasi manusia dan salah satu unsur kesejahteraan yang harus diwujudkan sesuai dengan cita-cita bangsa Indonesia sebagaimana dimaksud dalam Pancasila dan Pembukaan UndangUndang Dasar Negara Republik Indonesia Tahun 1945. Hal ini dapat dilihat terutama sila Ke-5 dan dalam Pasal 28H dan Pasal 34 Undang-Undang Dasar 1945 (selanjutnya disingkat UUD 1945). Selanjutnya, dalam Pasal 5 ayat (2) Undang-Undang No. 36 Tahun 2009 Tentang Kesehatan (selanjutnya disingkat UU No. 36 Tahun 2009) ditegaskan "bahwa setiap orang mempunyai hak dalam memperoleh pelayanan kesehatan yang aman, bermutu dan terjangkau. Selain itu, pembangunan kesehatan pada dasarnya harus diselenggarakan pada prinsip perlindungan".

Hal ini sebagaimana ditegaskan dalam Pasal 2 UU No. 36 Tahun 2009, bahwa "Pembangunan kesehatan harus diselenggarakan berasaskan asas perlindungan". Artinya, bahwa pembangunan kesehatan harus dapat memberikan perlindungan dan kepastian hukum kepada pemberi dan penerima pelayanan kesehatan.

Melalui Sistem Jaminan Sosial Nasional (SJSN) sebagai salah satu bentuk perlindungan sosial, pada hakekatnya bertujuan untuk menjamin seluruh rakyat agar dapat memenuhi kebutuhan dasar hidupnya yang layak. Untuk mewujudkan komitmen global sebagaimana amanat resolusi WHA ke-58 tahun 2005 di Jenewa yang menginginkan setiap negara 
mengembangkan Universal Health Coverage (UHC) bagi seluruh penduduk maka pemerintah bertanggung jawab atas pelaksanaan Jaminan Kesehatan masyarakat melalui program Jaminan Kesehatan Nasional (JKN).

Selanjutnya, untuk mengatasi hal tersebut pada tahun 2004 dikeluarkan Undang-Undang Nomor 40 Tahun 2004 (selanjutnya disingkat UU No. 40 Tahun 2004) yang mengamanatkan bahwa program jaminan sosial wajib bagi seluruh penduduk termasuk program Jaminan Kesehatan melalui suatu badan penyelenggaraan jaminan sosial. Badan penyelenggara jaminan sosial telah diatur dengan Undang-Undang Nomor 24 Tahun 2011 tentang Badan Penyelenggaran Jaminan Sosial (BPJS) yang terdiri dari BPJS ketanagakerjaan (selanjutnya disingkat UU No. 24 Tahun 2011). Untuk program Jaminan Kesehatan yang diselenggarakan oleh BPJS Kesehatan, implementasinya telah dimulai 1 Januari 2014. Program tersebut selanjutnya disebut sebagai program Jaminan Kesehatan Nasional (JKN).

Pedoman Pelaksanaan (Manlak), Petunjuk Teknis (Juknis) Selanjutnya, UU No. 40 Tahun 2004, secara khusus bahwa penyelenggaraan program jaminan sosial wajib bagi seluruh penduduk termasuk program jaminan kesehatan melalui suatu badan penyelenggara jaminan sosial. Oleh karena itu, setiap orang dapat akses atas sumber daya di bidang kesehatan dan memperoleh pelayanan kesehatan yang layak, aman, bermutu dan terjangkau.

Pengertian fraud atau kecurangan didalam JKN adalah tindakan yang dilakukan dengan sengaja oleh peserta, petugas BPJS Kesehatan, pemberi pelayanan kesehatan, serta penyedia obat dan alat kesehatan, untuk mendapatkan keuntungan finansial dari program jaminan kesehatan dalam sistem Jaminan Sosial Nasional melalui perbuatan curang yang tidak sesuai dengan ketentuan. ${ }^{1}$ Fraud dalam pelayanan kesehatan disebut sebagai suatu bentuk upaya yang secara sengaja dilakukan dengan menciptakan suatu keuntungan yang tidak seharusnya dinikmati baik oleh individu atau institusi dan dapat merugikan pihak lain.

Seperti yang telah dikemukakan di atas, kerugian dana jaminan sosial kesehatan akibat kecurangan (fraud) perlu adanya pencegahan dengan kebijakan nasional pencegahan kecurangan (fraud) agar dalam pelaksanaan program jaminan kesehatan nasional dalam sistem jaminan sosial nasional dapat berjalan dengan efektif dan efesien. Sebagaimana yang telah dikemukakan dalam Pasal 1 angka 1 Peraturan Menteri Kesehatan Republik Indonesia Nomor 36 Tahun 2015 Tentang Pencegahan Kecurangan (Fraud)

\footnotetext{
${ }^{1}$ Pasal 1 angka 1 Peraturan Menteri Kesehatan Republik Indonesia Nomor 36 Tahun 2015 Tentang Pencegahan Kecurangan (Fraud) Dalam Pelaksanaan Program Jaminan Kesehatan Pada Sistem Jaminan Sosial Nasional.
} 
Dalam Pelaksanaan Program Jaminan Kesehatan Pada Sistem Jaminan Sosial Nasional (Selanjutnya disingkat Permenkes No. 36 Tahun 2015).

Disebutkan bahwa kecurangan dalam pelaksanaan Jaminan Kesehatan Nasional dapat dilakukan oleh berbagai pihak seperti: peserta, petugas BPJS, pemberi pelayanan kesehatan dan penyedia obat dan alat kesehatan.

Pada prinsipnya fraud juga merupakan suatu tindakan penipuan/kecurangan untuk mendapatkan keuntungan bagi pelaku fraud atau bagi pihak lain. Fraud dapat dilakukan oleh peserta asuransi, penyelenggara asuransi dan Pemberi Pelayanan Kesehatan (PPK). Fraud pada PPK khususnya Rumah Sakit dapat disebabkan oleh ketidakpuasan Rumah Sakit terhadap tarif INACBG (singkatan dari Indonesia Case Base Groups yaitu sebuah aplikasi yang digunakan rumah sakit untuk mengajukan klaim pada pemerintah) dan ketidaksiapan sistem Informasi Teknologi di Rumah Sakit. Selain itu, adanya motivasi mencari "keuntungan ekonomi" dapat membuat PPK melakukan fraud.

Sebagaimana telah disebutkan di atas, bahwa dengan dikeluarkannya Permenkes No. 36 Tahun 2015 adalah sebagai salah satu upaya untuk pencegahan kecurangan (fraud) dalam pelaksanaan Program Jaminan Kesehatan Pada Sistem Jaminan Sosial Nasional.

Kecurangan (fraud) dalam BPJS perlu dilakukan pencegahan agar tidak menimbulkan kerugian. Hal ini sebagaimana diamanatkan dalam Pasal 7 Permenkes No. 36 Tahun 2015 bahwa dalam penyelenggaraan Program Jaminan Kesehatan dalam Sistem Jaminan Sosial Nasional, BPJS Kesehatan, Dinas Kesehatan Kabupaten/Kota, dan FKRTL yang bekerjasama dengan BPJS, harus membangun sistem pencegahan Kecurangan JKN. Dengan demikian rumah sakit sebagai FKRTL yang bekerjasama dengan BPJS harus harus membangun sistem pencegahan Kecurangan JKN.

Badan Layanan Umum Daerah (BLUD) Rumah Sakit Umum Daerah Menggala Kabupaten Tulang Bawang Propinsi Lampung merupakan rumah sakit milik Pemerintah Kabupaten Tulang Bawang yang juga rumah sakit rujukan BPJS atau rumah sakit yang menerima BPJS. Oleh karena itu, BLUD RSUD Menggala harus berkomitmen untuk mematuhi ketentuan yang terdapat Pasal 7 Permenkes No. 36 Tahun 2015. Dalam upaya memberikan pelayanan kesehatan BLUD RSUD Menggala telah memberikan fasilitas pelayanan kesehatan bagi peserta dan keluarganya yang terdaftar dalam BPJS dalam program Jaminan Kesehatan Nasional $(\mathrm{JKN})$. Dalam pelaksanaannya sering kali terjadi benturan-benturan atau kendala-kendala dalam pelaksanaan JKN tersebut di BLUD RSUD Menggala, baik yang disebabkan oleh peserta, petugas Rumah Sakit ataupun petugas BPJS itu sendiri. Sebagai contoh permasalahan yang timbul adalah penulisan kode diagnosis yang berkelebihan/upcoding, adanya klaim palsu/phantom billing dan memperpanjang lama perawatan/prolonged length 
of stay. Bagaimana sistem pencegahan kecurangan (fraud) dalam pelaksanaan program Jaminan Kesehatan pada sistem Jaminan Sosial Nasional (SJSN) di BLUD RSUD Menggala?; Bagaimanakah sistem pengaduan dan penyelesaian perselisihan jika terdapat kecurangan (fraud) dalam dalam pelaksanaan program Jaminan Kesehatan pada sistem Jaminan Sosial Nasional (SJSN) di BLUD RSUD Menggala?

\section{B. Pembahasan}

1. Sistem Pencegahan Kecurangan (Fraud) Dalam Pelaksanaan Program Jaminan Kesehatan Pada Sistem Jaminan Sosial Nasional (SJSN) Di BLUD RSUD Menggala

Menurut ketentuan Pasal 7 Permenkes Nomor 36 Tahun 2015 bahwa dalam penyelenggaraan Program Jaminan Kesehatan dalam Sistem Jaminan Sosial Nasional, BPJS Kesehatan, Dinas Kesehatan Kabupaten/Kota, dan FKRTL yang bekerjasama dengan BPJS, harus membangun sistem pencegahan kecurangan JKN. Namun demikian bagaimana sistem pencegahan kecurangan yang telah dilakukan oleh RSUD Menggala, terlebih dahulu perlu dikemukakan tentang lembaga atau institusi yang dimungkinkan untuk melakukan kecurangan. Menurut ketentuan Pasal 2 Permenkes Nomor 36 yang dapat melakukan kecurangan adalah: peserta, petugas BPJS Kesehatan, pemberi pelayanan kesehatan; dan/atau, penyedia obat dan alat kesehatan.

Pada prinsipnya peserta JKN berpotensi untuk melakukan kecurangan sebagaimana yang telah dikemukakan pada halaman 49 dan 50. Kecurangan yang dilakukan oleh peserta, sebagaimana ditentukan dalam Pasal 3 Permenkes Nomor 36 Tahun 2015 dapat berupa:

a. Membuat pernyataan yang tidak benar dalam hal eligibilitas (memalsukan status kepesertaan) untuk memperoleh pelayanan kesehatan;

b. Memanfaatkan haknya untuk pelayanan yang tidak perlu (unneccesary services) dengan cara memalsukan kondisi kesehatan;

c. Memberikan gratifikasi kepada pemberi pelayanan agar bersedia memberi pelayanan yang tidak sesuai/tidak ditanggung;

d. Memanipulasi penghasilan agar tidak perlu membayar iuran terlalu besar;

e. Melakukan kerjasama dengan pemberi pelayanan untuk mengajukan klaim palsu;

f. Memperoleh obat dan/atau alat kesehatan yang diresepkan untuk dijual kembali; dan/atau

g. Melakukan tindakan kecurangan JKN lainnya selain huruf a sampai dengan huruf $f$. 
Kerugian juga tidak hanya dilakukan oleh peserta JKN saja, akan tetapi justru dilakukan oleh petugas BPJS Kesehatan itu sendiri. Hal ini sebagaimana tertuang dalam ketentuan Pasal 4 Permenkes Nomor 36 Tahun 2015, bahwa Tindakan Kecurangan JKN yang dilakukan oleh petugas BPJS Kesehatan meliputi:

a. Melakukan kerjasama dengan peserta dan/atau fasilitas kesehatan untuk mengajukan klaim yang palsu;

b. Memanipulasi manfaat yang seharusnya tidak dijamin agar dapat dijamin;

c. Menahan pembayaran ke fasilitas kesehatan/rekanan dengan tujuan memperoleh keuntungan pribadi;

d. Membayarkan dana kapitasi tidak sesuai dengan ketentuan; dan/atau

e. Melakukan tindakan Kecurangan JKN lainnya selain huruf a sampai dengan huruf $d$.

Bentuk kecurangan yang paling klasik dilakukan oleh petugas BPJS adalah kerjasama dengan peserta dan/atau fasilitas kesehatan untuk mengajukan klaim yang palsu serta memanipulasi manfaat yang seharusnya tidak dijamin agar dapat dijamin. Kondisi demikian juga terungkat berdasarkan hasil wawancara dengan Staf RSUD Menggala bahwa dimungkinkan peserta akan bekerjasama dengan petugas BPJS. ${ }^{2}$

Untuk tindakan kecurangan JKN yang dilakukan di FKRTL menurut Pasal Pasal 5 Permenkes Nomor 36 Tahun 2015 meliputi:

a. Penulisan kode diagnosis yang berlebihan/upcoding, yaitu pengubahan kode diagnosis dan/atau prosedur menjadi kode yang memiliki tarif yang lebih tinggi dari yang seharusnya.

b. Penjiplakan klaim dari pasien lain/cloning, yaitu klaim yang dibuat dengan cara menyalin dari klaim pasien lain yang sudah ada.

c. Klaim palsu/phantom billing adalah klaim atas layanan yang tidak pernah diberikan.

d. Penggelembungan tagihan obat dan alkes/inflated bills, yaitu klaim atas biaya obat dan/atau alat kesehatan yang lebih besar dari biaya yang sebenarnya.

e. Pemecahan episode pelayanan/services unbundling or fragmentation, yaitu klaim atas dua atau lebih diagnosis dan/atau prosedur yang seharusnya menjadi satu paket pelayanan dalam episode yang sama atau menagihkan beberapa prosedur secara terpisah yang seharusnya dapat ditagihkan bersama dalam bentuk paket pelayanan, untuk mendapatkan nilai klaim lebih besar pada satu episode perawatan pasien.

f. Rujukan semu/selfs-referals, adalah klaim atas biaya pelayanan akibat rujukan ke dokter yang sama di fasilitas kesehatan lain kecuali dengan alasan fasilitas.

\footnotetext{
${ }^{2}$ Wawancara dengan Staf RSUD Menggala 5 April 2016.
} 
g. Tagihan berulang/repeat billing, adalah klaim yang diulang pada kasus yang sama.

h. Memperpanjang lama perawatan/prolonged length of stay, adalah klaim atas biaya pelayanan kesehatan yang lebih besar akibat perubahan lama hari perawatan inap.

i. Memanipulasi kelas perawatan/type of room charge, adalah klaim atas biaya pelayanan kesehatan yang lebih besar dari biaya kelas perawatan yang sebenarnya.

j. Membatalkan tindakan yang wajib dilakukan/cancelled services, adalah klaim atas diagnosis dan/atau tindakan yang tidak jadi dilaksanakan.

k. Melakukan tindakan yang tidak perlu/no medical value, adalah klaim atas tindakan yang tidak berdasarkan kebutuhan atau indikasi medis.

1. Penyimpangan terhadap standar pelayanan/standard of care, adalah klaim atas diagnosis dan/atau tindakan yang tidak sesuai dengan standar pelayanan.

m. Melakukan tindakan pengobatan yang tidak perlu/unnecessary treatment, adalah klaim atas tindakan yang tidak diperlukan.

n. Menambah panjang waktu penggunaan ventilator, adalah klaim yang lebih besar akibat penambahan lama penggunaan ventilator yang tidak sesuai dengan kebutuhan.

o. Tidak melakukan visitasi yang seharusnya/phantom visit, adalah klaim atas kunjungan pasien palsu.

p. Tidak melakukan prosedur yang seharusnya/phantom procedures, adalah klaim atas tindakan yang tidak pernah dilakukan.

q. Admisi yang berulang/readmisi, adalah klaim atas diagnosis dan/atau tindakan dari satu episode yang dirawat atau diklaim lebih dari satu kali seolah-olah lebih dari satu episode.

Selanjutnya, tindakan kecurangan JKN yang dilakukan penyedia obat dan alat kesehatan menurut ketentuan Pasal 2 Permenkes Nomor 36 Tahun 2015 meliputi:

a. Tidak memenuhi kebutuhan obat dan/atau alat kesehatan sesuai dengan ketentuan peraturan perundang-undangan;

b. Melakukan kerjasama dengan pihak lain mengubah obat dan/atau alat kesehatan yang tercantum dalam e-catalog dengan harga tidak sesuai dengan $e$-catalog; dan melakukan tindakan kecurangan $\mathrm{jkn}$ lainnya selain huruf a dan huruf $b$.

Sebagai contoh konkret, tindak kecurangan (fraud) yang mungkin terjadi di tingkat FKRTL adalah penulisan kode diagnosis yang berlebihan (upcoding). Bentuk tindak kecurangan ini dipicu oleh beberapa hal, misalnya karena merasa biaya yang tercantum dalam paket INA-CBGs dirasa rendah maka rumah sakit mencari cara lain untuk mendapat keuntungan. Pembayaran klaim BPJS Kesehatan ke rumah sakit sebagaimana paket tarif 
INA-CBGs yang tanpa batas atas juga memicu terjadinya fraud. Selain itu, peraturan perundang-undangan yang ada saat ini seperti UU No.40 Tahun 2004 tentang SJSN dan UU No.24 Tahun 2011 tentang BPJS belum cukup kuat mencegah kecurangan.

Selanjutnya, Permenkes No. 36 Tahun 2015 memerintahkan masingmasing pihak terkait untuk membangun sistem pencegahan tindak kecurangan (fraud). Untuk BPJS Kesehatan Permenkes 36 Tahun 2015 memerintahkan penyusunan kebijakan dan pedoman pencegahan Kecurangan JKN, pengembangan budaya pencegahan kecurangan JKN sebagai bagian dari tata kelola organisasi yang baik dan pembentukan tim pencegahan kecurangan JKN di BPJS Kesehatan. FKRTL harus membentuk sistem serupa sebagaimana diamanatkan Permenkes 36 Tahun 2015. Peran masyarakat juga dibutuhkan untuk mencegah kecurangan dalam program JKN, karena setiap orang yang mengetahui adanya kecurangan dalam program JKN dapat melakukan pengaduan. Caranya, pengadu menyampaikan secara tertulis kepada pimpinan fasilitas kesehatan, dinas kesehatan Kabupaten/Kota dan atau Provinsi. Pengaduan harus dilengkapi data identitas pengadu, kemudian nama dan alamat instansi yang diduga melakukan tindakan kecurangan dan alasan pengaduan.

Pembangunan sistem pencegahan kecurangan menurut Permenkes No. 36 Tahun 2015 harus melalui tiga hal yakni:

a. FKRTL menyusun peraturan internal dalam bentuk tata kelola organisasi dan tata kelola klinik yang baik.

b. FKRTL mampu mengembangkan pelayanan kesehatan yang berorientasi kepada kendali mutu dan kendali biaya melalui penggunaan konsep manajemen yang efektif dan efisien, teknologi informasi berbasis bukti dan membentuk Tim Pencegahan Kecurangan JKN di FKRTL.

c. FKRTL mampu mengembangkan budaya pencegahan kecurangan JKN sebagai bagian dari tata kelola organisasi dan tata kelola klinis yang berorientasi kepada kendali mutu dan kendali biaya berdasarkan prinsip TARIK (transparansi, akuntabilitas, responsibilitas, independensi dan kewajaran).

Kecurangan (fraud) yang ditemukan di RSUD Menggala dilakukan sebagai berikut: ${ }^{3}$

a. Petugas BPJS

1) Fraud yang dilakukan oleh petugas BPJS Kesehatan di RSUD Menggala:

a) Tidak memberikan definisi yang jelas tentang pelayanan satu episode.

b) Tidak memberikan bukti tertulis terhadap suatu penolakan diagnosis atau jenis pelayanan.

\footnotetext{
${ }^{3}$ Wawancara dengan Staf RSUD Menggala 10 April 2016.
} 
Kedua kecurangan diatas dapat mengakibatkan kerugian bagi RSUD Menggala disebabkan klaim atas pelayanan yang telah dilakukan tidak dapat dibayarkan.

2) Bentuk Pencegahan :

a) Membentuk Tim di RSUD Menggala untuk menyatukan pendapat dan atau mencari pedoman atau peraturan tertulis untuk mendapatkan jalan keluar terbaik sehingga tidak menggangu proses pelayanan di RSUD Menggala dan diharapkan kalim dapat dibayarkan.

b) Apabila tidak menemukan titik temu maka pihak rumah sakit melaporkan secara tertulis kepada Tim Kendali Mutu Kendali Biaya (TKMKB) Provinsi Lampung. Selanjutnya pihak BPJS melaporkan ke Dewan Pertimbangan Medik (DPM) Provinsi Lampung.

b. Peserta JKN

1) Fraud yang dilakukan peserta JKN

a) Membuat pernyataan yang tidak benar dalam hal eligibilitas (memalsukan status kepesertaan) untuk memperoleh pelayanan kesehatan.

b) Memanfaatkan haknya untuk pelayanan yang tidak perlu (unnecessary service) dengan cara memalsukan kondisi kesehatan.

2) Bentuk pencegahannya :

a) RSUD Menggala menambahkan persyaratan untuk menyertakan KTP dan Kartu Keluarga Asli selain kartu JKN /KIS (Kartu Indonesia Sehat) dalam hal penerbitan Surat Eligibilitas Peserta (SEP).

b) BPJS Kesehatan melakukan wawancara dengan pasien maupun keluarga pasien tentang kondisi kesehatan pasien, sehingga kondisi pasien yang sesungguhnya dapat diketahui.

c. RSUD Menggala

1) Fraud yang dilakukan oleh RSUD Menggala yaitu :

a) Penulisan kode diagnosis yang berlebihan/upcoding untuk mendapatkan jasa yang lebih tinggi.

b) Pemecahan episode pelayanan/service unbundling or fragmentation.

c) Merubah tanggal perawatan pasen rawat inap.

2) Bentuk pencegahannya :

Sesuai dengan Permenkes No. 36 Tahun 2015 maka Direktur RSUD Menggala membuat Surat Edaran No.800/875/III.12/TB/IX/2015 Tentang Upaya Pencegahan fraud di RSUD Menggala meliputi :

a) Dalam memberikan pelayanan kesehatan kepada masyarakat harus secara optimal dan berorientasi kepada kendali mutu dan kendali biaya.

b) Dalam memberikan pelayanan harus sesuai dengan Standar Pelayanan Minimal (SPM), Pedoman Pelayanan Klinis dan clinical pathway.

c) Melakukan audit klinis. 
d) Dalam mengajukan klaim harus sesuai dengan prosedur klaim yang telah ditetapkan.

Selanjutnya dengan memperhatikan Permenkes No. 36 Tahun 2015 Paragraf kedua Tentang Tim Pencegahan Kecurangan JKN di Fasilitas Kesehatan Rawat Tingkat Lanjutan (FKRT) maka Direktur RSUD Menggala Membentuk Tim Pencegahan Fraud dengan Nomor SK 800/876/III.12/TB/IX/2015 Tentang Tim Pencegahan Fraud di RSUD Menggala yang terdiri dari: Ketua Tim (Ketua Satuan Pengawas Internal), Sekretaris: Kepala Bidang Pelayanan, Anggota: Ketua Komite Medik, Perekam Medis, Koder, Ketua Komite Keperawatan. Tim ini bertugas:

a. Melakukan deteksi dini kecurangan JKN di BLUD RSUD Menggala berdasarkan data klaim pelayanan yang dilakukan.

b. Mensosialisasikan kebijakan, regulasi dan budaya baru yang berorientasi pada kendali mutu dan kendali biaya.

c. Meningkatkan kemampuan koder serta dokter dan petugas lain yang berkaitan dengan klaim.

d. Melakukan upaya pencegahan, deteksi dan penindakan kecurangan JKN.

e. Melakukan monitoring dan evaluasi.

f. Melakukan pelaporan kepada Direktur RSUD Menggala enam bulan sekali.

Sesuai dengan Paragraf 3 Tentang Kegiatan Pencegahan Kecurangan JKN di FKRTL Pasal 20 Permenkes No. 36 Tahun 2015 maka dalam melakukan tugasnya Tim ini melakukan kegiatan sebagai berikut:

a. Peningkatan kemampuan koder

Identifikasi faktor-faktor penting atau meningkatkan akurasi koding untuk mencegah kesalahan. Edukasi tentang pengetahuan kecurangan JKN, pelatihan dan edukasi koding yang benar, meningkatkan interaksi dengan staf klinis dalam rangka memastikan diagnose sekunder dan primer.

b. Peningkatan kemampuan dokter serta petugas lain yang berkaitan dengan klaim, yaitu dengan cara: pemahaman dan penggunaan sistem koding yang berlaku, melakukan edukasi dan pemberian pemahaman tentang langkah-langkah pencegahan, meningkatkan ketaatan terhadap standar prosedur operasional, menulis dan memberikan resume medis secara jelas, lengkap dan tepat waktu.

c. Melakukan analisis data klaim secara manual maupun menggunakan aplikasi verifikasi klinis yang terintregrasi dengan aplikasi INA-CBG

d. Dalam melakukan tugasnya Tim Pencegahan Fraud melaporkan kepada Direktur sebagai Pimpinan RSUD Menggala, tentang ada atau tidaknya kecurangan JKN yang ditemukan, rekomendasi pencegahan berulangnya kejadian serupa di kemudian hari dan rekomendasi sanksi administratif bagi pelaku kecurangan khususnya yang dilakukan oleh petugas BLUD RSUD Menggala. 
Hal yang cukup penting dalam pencegahan adanya kecurangan JKN di RSUD Menggala adalah memberikan pelayanan harus sesuai dengan Standar Pelayanan Minimal (SPM) sebagaimana yang diatur dalam Kepmenkes No. 129 Tahun 2008 Tentang Standar Pelayanan Medis di Rumah Sakit, Pedoman Pelayanan Klinis dan clinical pathway.

Adapun tujuan yang ingin dicapai melalui clinical pathways sebagai salah satu cara untuk mencegah kecurangan JKN adalah sebagai berikut: ${ }^{4}$

a. Menjamin suatu pelayanan yang konsisten, dengn kualitas yang bermutu yang didasarkan atas praktik yang terbaik (best practice) dan mengurangi variasi pelayanan yang tidak perlu. Oleh karena itu bila dikaitkan dengan JKN, akan menutup celah adanya manipulasi ataupun bentuk kecurangan lainnya. Hal ini sebagaimana ditegaskan dalam Pasal 29 ayat (1) huruf b UU No. 44 Tahun 2009 tentang Rumah Sakit, bahwa rumah sakit berkewajiban memberikan pelayanan kesehatan yang aman, bermutu, anti diskriminasi, dan efektif dengan mengutamakan kepentingan pasien sesuai dengan standar pelayanan rumah sakit. Selain itu, setiap tenaga kesehatan yang bekerja di rumah sakit harus bekerja sesuai dengan standar profesi, standar pelayanan rumah sakit, standar prosedur operasional yang berlaku, etika profesi, menghormati hak pasien dan mengutamakan keselamatan pasien (Pasal 13 ayat (3) UU No. 44 Tahun 2009). ${ }^{5}$

b. Meningkatkan kepuasan pasien dan keluarganya dengan menjelaskan rencana asuhan medis yang diperoleh selama dalam perawatan. Mengenai rencana asuhan medis dalam konteks ini erat hubungannya dengan kewajiban rumah sakit yang telah ditetapkan dalam Pasal 29 ayat (1) huruf a dan huruf 1 UU No. 44 Tahun 2009, yaitu: rumah sakit berkewajiban memberikan informasi yang benar tentang pelayanan rumah sakit kepada masyarakat (pasien) dan memberikan informasi yang benar, jelas dan jujur mengenai hak dan kewajiban pasien. Selain itu,

${ }^{4}$ Suharjo B. Cahyono, Op Cit. P. 311

${ }^{5}$ Yang dimaksud dengan standar profesi adalah batasan kemampuan (capacity) meliputi pengetahuan (knowledge), keterampilan (skill), dan sikap profesional (professional attitude) yang minimal harus dikuasai oleh seorang individu untuk dapat melakukan kegiatan profesionalnya pada masyarakat secara mandiri yang dibuat oleh organisasi profesi. Yang dimaksud dengan standar pelayanan Rumah Sakit adalah pedoman yang harus diikuti dalam menyelenggarakan Rumah Sakit antara lain Standar Prosedur Operasional, standar pelayanan medis, dan standar asuhan keperawatan. Yang dimaksud dengan standar prosedur operasional adalah suatu perangkat instruksi/langkah-langkah yang dibakukan untuk menyelesaikan proses kerja rutin tertentu. Standar prosedur operasional memberikan langkah yang benar dan terbaik berdasarkan konsensus bersama untuk melaksanakan berbagai kegiatan dan fungsi pelayanan yang dibuat oleh sarana pelayanan kesehatan berdasarkan standar profesi. Yang dimaksud dengan etika profesi adalah kode etik yang disusun oleh asosiasi atau ikatan profesi. 
informasi yang diberikan oleh rumah sakit juga berkaitan dengan masalah informed consent. Informed Consent adalah persetujuan tindakan kedokteran yang diberikan oleh pasien atau keluarga terdekatnya setelah mendapatkan penjelasan secara lengkap mengenai tindakan kedokteran yang akan dilakukan terhadap pasien tersebut. Penjelasan tentang tindakan kedokteran menurut ketentuan Pasal 7 ayat (3) Permenkes No. 290/MENKES/PER/III/2008 Tentang Persetujuan Tindakan Kedokteran, sekurang-kurangnya mencakup:

1) Diagnosis dan tata cara tindakan kedokteran;

2) Tujuan tindakan kedokteran yang dilakukan;

3) Alternatif tindakan lain, dan risikonya;

4) Risiko dan komplikasi yang mungkin terjadi; dan

5) Prognosis terhadap tindakan yang dilakukan.

6) Perkiraan biaya.

Penyampaian informasi mengenai perkiraan biaya, di RSUD Menggala selalu diinformasikan kepada pasien, sebelum tenaga medis melakukan tindakan. Hal ini perlu disampaikan agar pasien atau keluarganya dapat mempersiapkan diri apabila ada beberapa komponen pelayanan medis yang tidak dijamin oleh BPJS. ${ }^{6}$

c. Menjamin pemberian pelayanan berdasarkan atas kebutuhan pasien. Artinya dalam dalam pemberian pelayanan medis tidak boleh under threatment atau over threatment. Bahkan menurut ketentuan Pasal 17 ayat (4) UU No. 44 Tahun 2009, ditegaskan bahwa penggunaan peralatan medis dan medis di rumah sakit harus dilakukan sesuai dengan medis pasien.

d. Menjadikan asuhan medis lebih efisien dengan cara menentukan lama perawatan dan penggunaan tes dan terapi standar.

e. Mengurangi beban proses pendokumentasian klinis baik bagi perawat maupun dokter.

f. Memungkinkan tim multidisipliner berkomunikasi dan berkoordinasi secara lebih efektif.

g. Memberi kesempatan bagi pemberi pelayanan agar dapat mempelajari seberapa sering dan mengapa rencana yang tertulis tidak dilaksanakan.

Dikarenakan salah satu titik rawan terjadinya kecurangan JKN itu berada di fasilitas kesehatan atau rumah sakit, maka dengan adanya clinical pathways dalam melayani pasien di rumah sakit, setidak-tidaknya akan memberikan efisiensi dan efektivitas dalam pelayanan medis, serta untuk mencegah adanya kecurangan dalam pembiayaan perawatan medis di rumah sakit. Menurut informasi yang diperoleh di RSUD Menggala, seringkali para tenaga medis dan tenaga keperawatan dalam memberi pelayanan medis tidak

\footnotetext{
${ }^{6}$ Wawancara dengan Staf RSUD Menggala 10 April 2016.
} 
menuliskan secara stuktur, akibatnya terjadi inefisiensi dalam pelayanan medis. ${ }^{7}$ Menurut beberapa studi yang telah dilakukan membuktikan bahwa implementasi clinical pathways dapat mengurangi masa rawat inap di rumah sakit 5-40\% dan menurunkan biaya rawat inap sampai 30\%, mengurangi infeksi luka operasi dan angka perawatan kembali (readmission rates), dan memperbaiki outcome klinis lainnya. ${ }^{8}$

Selanjutnya secara khusus Permenkes No. 36 Tahun 2015 mewajibkan FKRTL membangun sistem pencegahan kecurangan, namun belum menjelaskan standar minimum yang jelas sistem pencegahan seperti apa yang perlu dibangun FKRTL. Standar diserahkan ke FKRTL, sehingga perlu adanya standarisasi sistem pencegahan yang dibangun oleh FKRTL untuk meminimalkan subyektifitas pemilik atau pejabat FKRTL dalam membangun sistem pencegahan.

Permenkes No.36 Tahun 2015 mengatur pembinaan dan pengawasan dalam rangka pencegahan kecurangan dalam JKN dilakukan oleh Menteri, Kepala Dinas Kesehatan Provinsi dan Kepala Dinas Kesehatan Kabupaten/Kota sesuai dengan kewenangan masing-masing. Bentuk pembinaan dan pengawasan itu berupa advokasi, sosialisasi dan bimbingan teknis, pelatihan dan peningkatan kapasitas SDM serta monitoring dan evaluasi. Selanjutnya, Permenkes 36 Tahun 2015 mengatur sanksi bagi pelaku kecurangan. Sanksi administratif yang dapat dijatuhkan kepada pelaku yaitu teguran lisan, teguran tertulis dan/atau perintah pengembalian kerugian kepada pihak yang dirugikan. Sanksi administrasi tersebut pada prinsipnya tidak menghapus pidana yang dapat dijatuhkan kepada pelaku kecurangan atau penipuan sebagaimana yang diatur dalam Pasal 378 KUHP. Artinya, penerapan sanksi administratif harus sinergis dengan sanksi pidana. Oleh karena itu, di masa mendatang perlu dibuat peraturan khusus yang mengatur tentang fraud, bentuknya bisa berupa undang-undang Anti Fraud dalam Pelayanan Kesehatan.

\section{Sistem Pengaduan Dan Penyelesaian Perselisihan Jika Terdapat Kecurangan (Fraud) dalam Pelaksanaan Program Jaminan Kesehatan Pada Sistem Jaminan Sosial Nasional (SJSN) Di BLUD RSUD Menggala}

Pengaduan dapat disampaikan kepada pimpinan fasilitas kesehatan, Dinas Kesehatan Kabupaten/Kota dan/atau Dinas Kesehatan Provinsi (Pasal 25 ayat (2) Permenkes No. 36 Tahun 2015). Pengaduan pada fasilitas kesehatan dalam hal ini adalah rumah sakit, baik FKTP maupun FKRLT.

\footnotetext{
${ }^{7}$ Wawancara dengan Staf RSUD Menggala 6 Mei 2016.

${ }^{8}$ Suharjo B. Cahyono, Op Cit. p. 315
} 
Pengaduan di FKTP ditujukan kepada tim pencegahan Kecurangan JKN di FKTP yang dibentuk oleh Dinas kesehatan Kabupaten/Kota. Tim pencegahan Kecurangan JKN di FKTP terdiri atas unsur dinas kesehatan, organisasi profesi, BPJS Kesehatan, dan asosiasi fasilitas kesehatan. Menurut ketentuan Pasal 11 ayat (4) Permenkes No. 36 Tahun 2015 Tim pencegahan Kecurangan JKN di FKTP sebagaimana dimaksud pada ayat (2) bertugas:

a. Mensosialisasikan kebijakan, pedoman, dan budaya baru yang berorientasi pada kendali mutu dan kendali biaya;

b. Mendorong pelaksanaan tata kelola organisasi dan tata kelola klinik yang baik;

c. Melakukan upaya pencegahan, deteksi dan penindakan kecurangan JKN di FKTP;

d. Menyelesaikan perselisihan kecurangan JKN;

e. Monitoring dan evaluasi; dan

f. Pelaporan.

Jadi berdasarkan Pasal 11 ayat (4) Permenkes No. 36 Tahun 2015 tersebut, Tim Pencegahan Kecurangan JKN di FKTP melakukan penindakan kecurangan JKN dan menyelesaikan penyelesaian perselisihan JKN berdasarkan suatu laporan atau penemuan. Berdasarkan hasil wawancara dengan Staf RSUD Menggala, ${ }^{9}$ laporan atau pengaduan adanya kecurangan JKN ditujukan kepada Tim Pencegahan Fraud di RSUD Menggala yang terdiri dari: Ketua Tim (Ketua Satuan Pengawas Internal), Sekretaris: Kepala Bidang Pelayanan, Anggota : Ketua Komite Medik, Perekam Medis, Koder, Ketua Komite Keperawatan. Salah satu tugas Tim adalah penindakan kecurangan JKN. Oleh karena itu, di RSUD Menggala laporan adanya dugaan kecurangan JKN sudah di bentuk Tim yang sesuai dengan ketentuan Pasal 11 ayat (1) Permenkes No. 36 Tahun 2015. Dengan kata lain ketersediaan saluran pengaduan kecurangan JKN di RSUD Menggala sudah terbangun. Dalam hal ini RSUD Menggala telah membuat sistem pencegahan kecurangan JKN paling lambat 6 (enam ) bulan sejak Permenkes No. 36 Tahun 2015, diundangkan. Tindakan ini sesuai dengan ketentuan Pasal 30 ayat (2) Permenkes No. 36 Tahun 2015 yang berbunyi: "Kepala Dinas Kesehatan Kabupaten/Kota, direktur/kepala rumah sakit dan penanggungjawab klinik utama atau yang setara harus membuat sistem pencegahan kecurangan JKN paling lambat 6 (enam) bulan sejak Peraturan Menteri ini diundangkan". Kondisi demikian juga akan berkaitan dengan tata kelola perusahaan yang baik (good corporate governance), dan tata kelola klinis yang baik (good clinical governance) dalam sebuah rumah sakit. sebagaimana tertuang dalam Pasal 16 Permenkes No. 36 Tahun 2015 yaitu:

\footnotetext{
${ }^{9}$ Wawancara dengan Staf RSUD Menggala 10 Juni 2016.
} 
a. Transparansi merupakan keterbukaan informasi, baik dalam proses pengambilan keputusan maupun dalam mengungkapkan informasi yang sesuai dengan kebutuhan untuk pencegahan Kecurangan JKN.

b. Akuntabilitas merupakan kejelasan fungsi struktur sistem dan pertanggungjawaban pelayanan sehingga pengelolaan terlaksana dengan efektif.

c. Responsibilitas merupakan kesesuaian atau kepatuhan di dalam pengelolaan pelayanan terhadap prinsip organisasi yang sehat dalam rangka pencegahan kecurangan JKN.

d. Independensi merupakan suatu keadaan dimana organisasi dikelola secara profesional tanpa benturan kepentingan dan pengaruh atau tekanan dari pihak manapun yang tidak sesuai dengan prinsip-prinsip organisasi yang sehat dalam rangka pencegahan kecurangan JKN.

e. Kewajaran merupakan perlakuan yang adil dan setara di dalam memenuhi hak pemangku kepentingan yang timbul berdasarkan perjanjian dalam rangka pencegahan kecurangan JKN.

Good corporate governance di bidang perumahsakitan merupakan suatu sistem (tata) hubungan dalam organisasi rumah sakit yang mengandung unsur-unsur pengendalian, pengarahan, pertanggungjawaban, dan pertanggung gugatan antara pemilik, pengelola, dan direksi serta jajaran manajemen operasional sebagai suatu kesatuan gerak untuk mencapai visi dan misi nilai-nilai organisasi. Tata kelola yang baik dan sehat melalui prinsip corporate governance akan menjamin kelangsungan dan perkembangan rumah sakit. Prinsip-prinsip yang dikembangkan dalam corporate governance adalah keterbukaan, akuntabilitas, pertanggungjawaban kepada pemberi tugas, integritas dan berkeadilan.

Selanjutnya, dengan merujuk pada ketentuan Pasal 27 ayat (2) Permenkes No. 36 Tahun 2015, pembinaan dan pengawasan pencegahan kecurangan JKN di RSUD Menggala telah melibatkan badan pengawas rumah sakit, dewan pengawas rumah sakit, perhimpunan/asosiasi perumahsakitan, dan organisasi profesi. ${ }^{10}$ Salah satu komponen dalam pengawasan tersebut adalah mengawasi kepatuhan penerapan etika rumah sakit, etika profesi, dan peraturan perundang-undangan termasuk di dalamnya Permenkes No. 36 Tahun 2015.

Untuk pengaduan adanya dugaan kecurangan JKN, harus memuat paling sedikit meliputi: identitas pengadu, nama dan alamat instansi yang diduga melakukan tindakan kecurangan JKN, dan alasan pengaduan (Pasal 25 ayat (3) Permenkes No. 36 Tahun 2015). Dengan adanya pengaduan kecurangan JKN, Pimpinan fasilitas kesehatan, Dinas Kesehatan Kabupaten/Kota dan/atau Dinas Kesehatan Provinsi harus menindaklanjuti

\footnotetext{
${ }^{10}$ Wawancara dengan Staf RSUD Menggala 15 Juni 2016.
} 
pengaduan dengan cara melakukan investigasi. Investigasi dilakukan dengan melibatkan BPJS Kesehatan, tim pencegahan Kecurangan JKN di FKRTL

\section{Penutup}

Untuk mencegah adanya kecurangan dalam BPJS terutama masalah penulisan kode diagnosis berkelebihan, klaim palsu dan tagihan berulang, di RSUD Menggala telah membentuk sistem pencegahan kecurangannya itu dengan membentuk Tim Pencegahan Fraud berdasarkan Surat Keputusan Direktur RSUD Menggala dengan Nomor SK 800/876/III.12/TB/IX/2015 Tentang Tim Pencegahan Fraud di RSUD Menggala. Salah satu tugas Tim tersebut adalah melakukan upaya pencegahan, deteksi dan penindakan kecurangan JKN. Sistem yang telah dibangun dalam upaya melakukan pencegahan JKN di RSUD Menggala telah sesuai dengan Permenkes Nomor. 36 Tahun 2015.

Kecurangan dalam bentuk penulisan kode diagnosis berkelebihan, klaim palsu dan tagihan berulang di RSUD Menggala dapat dilakukan melalui sistem pengaduan atau laporan adanya kecurangan JKN yang dilakukan secara tertulis yang ditujukan kepada Tim Pencegahan Fraud. Pengaduan atau laporan adanya dugaan kecurangan JKN, harus memuat paling sedikit meliputi: identitas pengadu, nama dan alamat instansi yang diduga melakukan tindakan Kecurangan JKN, dan alasan pengaduan. Apabila terjadi perselisihan pendapat terhadap penetapan ada tidaknya kecurangan JKN, Dinas Kesehatan Provinsi atau Dinas Kesehatan Kabupaten/Kota dapat meneruskan pengaduan kepada Tim pencegahan Kecurangan JKN yang dibentuk oleh Menteri.

\section{Daftar Pustaka}

\section{A. Buku dan Artikel Ilmiah}

Cahyono, S.B. (2008). Membangun Budaya Keselamatan Pasien. Yogyakarta: Kanisius.

Sabrina, Qisthi. (2015). "Pelaksanaan Program Jaminan Kesehatan Nasional (JKN) Dalam Peningkatan Kualitas Pelayanan Kesehatan di RSU Haji Surabaya". Jurnal Kebijakan dan Manajemen Publik, 3(2): 14.

Singleton, T. W., J. Aaron, (2010). Fraud Auditing and Forensic Accounting. John Wiley \& Sons, Inc.

Soejono, Karni. (2000). Auditing: Audit Khusus dan Audit Forensik dalam

Praktek. Jakarta: Lembaga Penerbitan FE UI.

Ta'adi. (2013). Hukum Kesehatan: Sanksi dan Motivasi Bagi Perawat. Jakarta: Buku Kedokteran EGC. 
Widjaja, Amin. (2012). Forensic \& Investigative Accounting: Pendekatan Kasus, Jakarta: Harvarindo.

\section{B. Peraturan Perundang-Undangan}

Undang-Undang Nomor 40 Tahun 2004 tentang Sistem Jaminan Sosial Nasional (SJSN). Lembaran Negara RI Tahun 2004, Sekretariat Negara. Jakarta.

Undang-Undang Nomor 36 Tahun 2009 tentang Kesehatan. Lembaran Negara RI Tahun 2009, Sekretariat Negara. Jakarta.

Undang-Undang Nomor 24 Tahun 2011 tentang Badan Penyelenggara Jaminan Sosial (BPJS). Lembaran Negara RI Tahun 2011, Sekretariat Negara. Jakarta.

Peraturan Menteri Kesehatan Republik Indonesia Nomor 36 Tahun 2015 Tentang Pencegahan Kecurangan (Fraud) Dalam Pelaksanaan Program Jaminan Kesehatan Pada Sistem Jaminan Sosial Nasional. Sekretariat Kabinet RI. Jakarta. 
